\title{
TYFLOGRAFIKA - SZANSA NA NOWE OBLICZE KSIĄŻKI NIEWIDOMEGO I OBECNOŚĆ JEJ UŻYTKOWNIKÓW W ŚWIECIE INFORMACJI? W KRĘGU ROZWAŻAŃ BIBLIOLOGICZNO- -TYFLOLOGICZNYCH
}

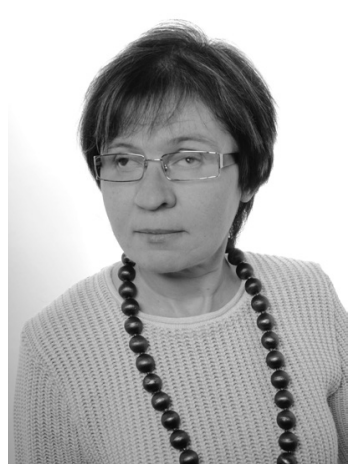

Małgorzata Czerwińska, dr hab. nauk humanistycznych w zakresie bibliologii i informatologii; związana również z pedagogiką specjalna, zwłaszcza tyflopedagogika; bibliotekoznawca, specjalista z zakresu informacji naukowej, nauczyciel; dziennikarz, profesor Uniwersytetu Zielonogórskiego. Przewodnicząca Rady Naukowej Wojewódzkiej i Miejskiej Biblioteki Publicznej im. C. Norwida w Zielonej Górze. Autorka ponad 80 publikacji recenzowanych (książki, wydawnictwa pod redakcja, hasła encyklopedyczne, artykuły w pracach zbiorowych i czasopismach) i około 250 publikacji prasowych (publicystyka społeczno-kulturalna, wywiady, felietonisty$\mathrm{ka}$, recenzje).

SŁOWA KLUCZOWE: Tyflografika. Ilustracja. Reprezentacja wypukła. Niewidomy. Procesy poznawcze. Edukacja. Rehabilitacja. Wykluczenie informacyjne. Inkluzja społeczna.

ABSTRAKT: Teza/cel artykułu - Opracowanie niniejsze jest próbą usystematyzowania podstawowej wiedzy z zakresu problematyki tyflografiki, czyli reprezentacji dotykowej dla niewidomych, tyflopsychologicznych uwarunkowań jej redagowania, produkcji, jej funkcji w procesie edukacji i rehabilitacji oraz inkluzyjnego znaczenia dla społecznego funkcjonowania osób z niepełnosprawnością wzroku, w tym dostępu do informacji i dóbr kultury. Celem jest wprowadzenie zagadnień rysunku reliefowego, jako elementu książki niewidomego, do obszaru nauk bibliologicznych. Metody badawcze - Na podstawie źródeł publikowanych i niepublikowanych oraz obserwacji uczestniczącej przedstawiono porównawcze ustalenia pojęciowe i terminologiczne z zakresu tradycyjnej ilustracji książkowej i tyflogra- 
fiki. Wyniki i wnioski - Dokonano zwięzłego opisu genezy i rozwoju tyflografiki na świecie i w Polsce, koncentrując się na fundamentalnym znaczeniu działalności Martina Kunza. Zaprezentowano współczesną systematyzację tyflografiki. Opierając się na podstawowej wiedzy tyflopsychologicznej na temat specyfiki procesów poznawczych u niewidomych, nakreślono kluczowe zasady przygotowywania poprawnych merytorycznie przedstawień tyflograficznych. Rozważania kończą postulaty badawcze oraz praktyczne, których realizacja warunkuje wypełnianie przez tyflografikę funkcji poznawczych, kształcących, wychowawczych, rozrywkowych, informacyjnych, edukacyjnych i rehabilitacyjnych.

\section{WPROWADZENIE}

Książka ilustrowana od wieków stanowi przedmiot szczególnej troski edytorów, cenny materiał biblioteczny. Wzbudza zainteresowanie i podziw czytelników. Problematyka ilustracji książkowej zajmowała wielu teoretyków i praktyków książki. O estetyce książki, jej strukturze estetycznej, sztuce (formie graficzno-plastycznej ), artystycznym wyposażeniu, formie artystycznej, zdobnictwie, architekturze, edytorstwie i ukształtowaniu typograficznym - pisali m.in.: Stefan Vrtel-Wierczyński (1951), Elżbieta Skierkowska (1969), Tekla Malinowska i Ludwik Syta (1981), Karol Głombiowski (1985), Janina Wiercińska (1986), Radosław Cybulski (1986). Na uwagę zasługuje tu piśmiennictwo Woli N. Lachowa (1978) i Małgorzaty Komzy (1987), odnoszące się do zagadnień sztuki książki, czy też Grażyny Lewandowicz-Nosal (2012), Marii Cackowskiej (2009a; 2009b; 2009/2010) - dotyczące ilustrowanej książki dziecięcej. Ciągle znaczące miejsce zajmuje publikacja Ireny Słońskiej (1977), relacjonująca w ujęciu psychologicznym zagadnienie odbioru ilustracji książkowej. Na ilustrację książkową jako istotny składnik książki, zwraca uwagę także Krzysztof Migoń (2003) stwierdzając, że książkę ilustrowaną utożsamia się najczęściej z książką literacką lub dla dzieci.

Poza głębszym zainteresowaniem bibliologów pozostawały inne typy książek ilustrowanych: naukowe, popularnonaukowe, szkolne, religijne, informacyjne, poradnikowe. Należnego miejsca w literaturze bibliologicznej nie posiada również problematyka ilustrowanej książki dla niewidomych. $\mathrm{Na}$ uwagę zasługuje tu publikacja autorska Małgorzaty Fedorowicz (2002) i inna tejże autorki przygotowana we współpracy z Magdaleną J. Cyrklaff (2016).

W badaniach tej książki, procesów bibliologicznych jej dotyczących, pełnionych przez nią funkcji, bibliologia sięgać musi do nauk tyflologicznych, czerpiąc z nich terminologię, wiedzę merytoryczną i praktyczną z zakresu psychospołecznego funkcjonowania osób z niepełnosprawnością wzroku (zwłaszcza procesów poznawczych), ich edukacji i rehabilitacji.

Na gruncie tyflopedagogiki problematyka książki z ilustracją dotykową nie ma bogatej literatury przedmiotu. Wymienić tu wypada pionierską pracę Wandy Szuman (1967), poświęconą specyfice odbioru rysunku przez 
dzieci niewidome. O redagowaniu prezentacji dotykowych w sposób tyflologicznie poprawny pisała Ewa Bendych (1994; 1995a; 1995b). Znaczące miejsce zajmują opracowania dotyczące nowoczesnych technik edukacji osób z niepełnosprawnością wzroku (Kaczmarek, red., 2003) i tworzenia tyflokartografii (Mendruń \& Oleksiak, red., 2010).

Ogromną wartość ma doświadczenie praktyczne i ustalenia teoretyczne siostry Elżbiety Więckowskiej z Zakładu dla Niewidomych w Laskach (Więckowska, 2009a; 2009b; 2011; Więckowska, red., 2011) oraz Aliny Talukder i Marka Jakubowskiego ze Specjalnego Ośrodka Szkolno-Wychowawczego w Owińskach k. Poznania (Talukder \& Jakubowski, 2003). Ważnym głosem $\mathrm{w}$ tyflopedagogicznym dyskursie na temat edukacyjno-rehabilitacyjnej wartości książek dotykowych dla dzieci niewidomych są publikacje Bożeny Kazanowskiej (2012) i Małgorzaty Czerwińskiej (2015).

Opracowanie niniejsze nie pretenduje do miana wyczerpującego. Jest próbą usystematyzowania podstawowej wiedzy z zakresu problematyki reprezentacji dotykowej dla niewidomych, uwarunkowań jej redagowania, produkcji, jej funkcji w procesie edukacji i rehabilitacji oraz inkluzyjnego znaczenia dla społecznego funkcjonowania osób z niepełnosprawnością wzroku, w tym dostępu do dóbr kultury.

Celem jest wprowadzenie zagadnień rysunku reliefowego jako elementu książki dla niewidomych do obszaru nauk bibliologicznych - zarówno w ich wymiarze teoretycznym, jak i praktycznym. Obowiązujące akty normatywne - powszechne (Konwencja ONZ o Prawach Osób Niepełnosprawnych) i resortowe (wytyczne IFLA) - czynią osobę z niepełnosprawnością (także z niepełnosprawnością wzroku) pełnoprawnym użytkownikiem bibliotek, zobowiązując je m.in. do gromadzenia alternatywnych materiałów bibliotecznych. Tymczasem wiedza bibliotekarzy (zwłaszcza z bibliotek publicznych, pedagogicznych, naukowych) na temat owych materiałów, ich specyfiki i przeznaczenia jest ciągle niedostateczna; ogranicza się na ogół do książki mówionej i rzadziej - brajlowskiej. Współczesne rozwiązania techniczne pozwalają na produkcję nowych źródeł informacji, np. tyflografiki - czego bibliotekarze (nie tylko z bibliotek szkół specjalnych) powinni mieć świadomość.

\section{ILUSTRACJA I TYFLOGRAFIKA - PORÓWNAWCZE ROZWAŻANIA POJĘCIOWE I TERMINOLOGICZNE}

W literaturze bibliologicznej ilustracją określa się: „utwór rysunkowy, malarski, graficzny, fotograficzny, umieszczony w rękopisie lub jakimkolwiek druku" (Wiercińska, 1986, s. 37). Ilustracja objaśnia, uzupełnia, interpretuje lub dopowiada tekst, a także wyzwala uczucia (emocje, przeżycia estetyczne). Ilustracją są sceny figuralne, pejzażowe, odnoszące się do tematu i treści książki - zajmujące całą stronę lub jej część. Przyjmuje ona 
również postać nagłówka, inicjału, finalika, przerywnika, frontispisu. Warunkiem jest jednak zależność od tekstu i podporządkowanie kompozycji typograficznej druku. W książce dziecięcej, jako szczególnie ważny jej element, ilustracja często dominuje nad tekstem.

Ze względu na temat rozróżnia się ilustrację: literacką, naukową i prasową (J.W., 1982; Wiercińska, 1986).

Wyróżnia się ilustracje: „ściśle powiązane z tekstem, konieczne do jego zrozumienia; uzupełniające tekst, niekonieczne do jego zrozumienia, ale rozszerzające zagadnienie, informujące o zjawiskach towarzyszących i wzbogacające szatę graficzną książki; wyłącznie zdobiące, nawiązujące do tekstu epoka, nastrojem" (Malinowska \& Syta, 1981, s. 106).

Praktykowane są dwa sposoby ilustrowania książki - opisowy i interpretacyjny. Ilustracja opisująca (typowa dla publikacji naukowych) wyjaśnia tekst przez demonstrację wyobrażenia wzrokowego, natomiast ilustracja interpretująca (właściwa dla utworów literackich) jest twórczym komentarzem treści dzieła (Głombiowski, 1980).

Ilustracja w książce dla niewidomych (tyflografika) nie jest prostym przeniesieniem ilustracji z publikacji dla widzącego odbiorcy - na wersję wypukłą. W polskiej literaturze naukowej nie ma ścisłej terminologii i definicji tyflografiki. Najczęściej mówi się o rysunku dla niewidomych, rysunku wypukłym, rysunku brajlowskim lub rysunku dotykowo dostępnym.

Trafną definicję zaproponował Marek Jakubowski, według którego: „,tyflografika to grafika dla niewidomych i słabowidzących, stanowiąca:

- graficzne odwzorowanie i przedstawienie rzeczywistości, przy zastosowaniu skali, proporcji i generalizacji, w sposób dostępny dotykowo osobom niewidomym,

- graficzne odwzorowanie i przedstawienie rzeczywistości, przy zastosowaniu skali, proporcji i generalizacji, dostępne wizualnie osobom o ograniczonej percepcji wzrokowej,

- graficzne odwzorowanie i przedstawienie rzeczywistości, przy zastosowaniu skali, proporcji i generalizacji, dostępne dotykowo i wzrokowo dla osób niewidomych i o ograniczonej percepcji wzrokowej" (Jakubowski, 2009b, s. 38).

W porównaniu z tradycyjną ilustracją książkową tyflografika rzadko stanowi typograficzną całość $\mathrm{z}$ tekstem; często występuje niezależnie od niego (np. albumy, atlasy). Dominuje tyflografika naukowa (w podręcznikach szkolnych) i literacka (w książkach dla dzieci) - o charakterze opisowym. Jest ściśle związana $\mathrm{z}$ tekstem, uzupełnia go. Nie stosuje się tyflografiki o charakterze wyłącznie ozdobnym. Tyflografika bowiem ma być pomocą dla niewidzącego odbiorcy w poznaniu, zrozumieniu i odwzorowaniu rzeczywistości (Jakubowski, 2009b).

Rozważania powyższe warto uzupełnić o pogląd Wolfganga Fromma, zdaniem którego: „rysunek dla niewidomych jest zespołem umieszczonych 
na płaszczyźnie, dotykowo czytelnych linii, znaków i powierzchni o zróżnicowanej fakturze, a także bardzo spłaszczoną płaskorzeźbą lub konturem płasko-wypukłym" (Fromm, 1983, s. nlb. 3).

\section{ILUSTRACJE DLA NIEWIDOMYCH - GENEZA I ROZWÓJ}

Początków tworzenia przedstawień wypukłych szukać należy w sięgających czasów starożytnych poszukiwaniach wypukłych pism dla niewidomych, opartych na konwencji oddawania linią wypukłą (lub wklęsłą) kształtu liter łacińskich. Rozkwit poszukiwań nastąpił w czasach nowożytnych. Przykładem może tu być grawerowanie liter łacińskich na twardym podłożu: systemy Kwintyliana, Francesco Lucasa (1517 r.), Erazma z Rotterdamu (1528 r.), Pero Nexii (1542 r.), Girolamo Cardano (1550 r.); kreślenie liter łacińskich wypukłą linią ciągłą: system pisma Walentyna Haüya (1784 r.), a następnie: Françoisa Lesueura, Guille'a, Pierre-Armanda Dufaux, Jamesa Galla, Thomasa M. Lucasa, Johna Alstona (1837 r.), Williama Moona (1847 r.); wykłuwanie kształtu liter łacińskich wypukłą linią punktową: pismo Melanii de Salignac, Marii Teresy von Paradis, system pisma szpilkowego Wilhelma Kleina (1809 r.), system Johanna Georga Knie (1818 r.) (Czerwińska, 1999).

Pierwsze prace tyflograficzne podjęto w szkole dla niewidomych w Paryżu, założonej w 1784 r. Kształty liter, mapy, rysunki wytłaczano w grubym papierze i kartonie (Czerwińska, 1999; Jakubowski, 2009b).

Znacząca jest tu też działalność Marii Teresy von Paradis (1759-1824), niewidomej kompozytorki, śpiewaczki i pianistki - zafascynowanej postacią Haüya, która wykonywała: mapy wypukłe, plany, narzędzia do pisania wypukłymi literami łacińskimi (Jakubowski, 2010).

Twórca papierowych tyflografik jest Martin Kunz (1847-1923) - szwajcarski tyflopedagog, dyrektor Zakładu dla Ociemniałych w Illzach. Jest on autorem ponad 90 opracowań tyflokartograficznych i dużej liczby nieskatalogowanych przedstawień reliefowych. Jego tyflomapy i tyflografiki były wykorzystywane jako pomoce dydaktyczne w większości zakładów dla niewidomych w Europie. Sygnowane reliefowym napisem literami łacińskimi KUNZ - ILLZACH posiadają ",czarnodrukowe" napisy jednocześnie po niemiecku, francusku, angielsku i włosku. Tyflografiki te miały „,skromne" opisy brajlowskie, ponieważ Kunz początkowo nie był zwolennikiem tego systemu pisma. Od 1870 r. (wystawa berlińska i paryska) tyflografiki Martina Kunza i sposoby ich wytwarzania stały się obowiązujące w Europie. Kunz stosował do tłoczenia grafik reliefowych gruby papier, karton i preszpan. Modyfikował sposoby wykonywania matryc.

Marek Jakubowski podaje, że mapa Hiszpanii (pierwsza masowo wydana tyflografika) została wytłoczona za pomocą dwóch płatów blachy miedzianej, w których (m.in. metodą „,czekanki”) ulokowano przedstawie- 
nie reliefowe tematu. Matryce wykonywano również z gliny i gipsu oraz mieszanek tych materiałów, z drewna gruszkowego, metodą rzeźbienia oraz uzupełniania wklejanymi tkaninami o jednoznacznych strukturach. Podjęto próby stosowania elementów kauczukowych na drewnianej płaskorzeźbie oraz galwanoplastyki. Z czasem zaczęto wykonywać matryce technologią mieszana, tj. stosując elementy m.in.: metalowe, drewniane, gipsowe, włókninę. Ilustracje Kunza były przedmiotem dyskusji na kongresie nauczycieli ze szkół dla niewidomych w 1895 r. w Monachium, zakończonej wnioskiem przyznającym rysunkowi wypukłemu duże znaczenie dydaktyczne. Z map i rysunków wytwarzanych przez M. Kuntza korzystano w wielu europejskich zakładach dla niewidomych (także we Lwowie, Bydgoszczy i Wrocławiu).

Następca Martina Kunza, K. Przyrembel, związany z Blindenstudienanstallt Breslau (Wrocław), opracował metodę wykonywania lutowanych matryc metalowych i tłoczenia z nich map tyflologicznych na preszpanie. Wydany przez niego w 1932 r. Atlas świata - jest uznawany za wzorcowe wydawnictwo tyflokartograficzne (Jakubowski, 2009a).

Egzemplarze historycznych i współczesnych tyflografik przechowywane są w muzeach tyflologicznych, archiwach, bibliotekach zagranicznych i krajowych ośrodków dla niewidomych (Marburg, Praga, Brno, Berlin, Lipsk, Paryż, Wiedeń, Louisville, Ottawa, Owińska k. Poznania, Laski k. Warszawy). Niestety, bardzo często składowane są w niewłaściwych warunkach lokalowych (piwnice, strychy), nie są inwentaryzowane. Ich wartość historyczna i tyflopedagogiczna jest niedoceniana.

W latach 80. XX w. w polskich ośrodkach szkolno-wychowawczych dla niewidomych pojawiły się urządzenia do tłoczenia rysunków w plastiku (tzw. brajlony). Tworzeniem grafik za ich pomocą zajęli się nauczyciele przedmiotów (Talukder, 2009).

Wymagało to wiele czasu i cierpliwości, dlatego tych pomocy wytwarzano mało. Jedynie Ośrodek w Laskach posiada do dziś sprawne urządzenia do tłoczenia, jak i setki matryc, które są efektem długoletniej pracy Elżbiety Iwańskiej; jej wiedza i doświadczenie miały znaczący wpływ na opracowanie zasad tworzenia rysunku wypukłego.

Trzeba tu również zaznaczyć, że polskie instytucje dla niewidomych otrzymywały na przełomie XX i XXI w. tyflomapy i tyflografiki z: Holandii, Danii, Szwecji, Norwegii i Niemiec.

Wraz z rozwojem technologii termoformowania pojawiły się urządzenia, które pozwalały na wykonywanie tyflografik o rozmiarach A3, A2 i większych. W ten sposób przygotowano w wydawnictwie dla niewidomych w Lipsku Atlas świata, czy też tyflomapy w Polskim Związku Niewidomych, przy współpracy z Państwowym Przedsiębiorstwem Wydawnictw Kartograficznych (aktualnie Główny Urząd Geodezji i Kartografii) (Atlas..., 2004; Atlas..., 2006). 
W 2005 r. Ministerstwo Edukacji Narodowej wyposażyło ośrodki dla dzieci niewidomych w urządzenia do tworzenia rysunków na papierze eksplozyjnym - drukarki laserowe, wygrzewarki, komputery z oprogramowaniem graficznym. Niestety, tyflopedagodzy nie przejawiali większego zainteresowania tworzeniem tyflografik.

Ogromne znaczenie dla rozwoju polskiej tyflografiki ma działalność siostry Elżbiety Więckowskiej z Zakładu dla Niewidomych w Laskach. Przypisuje ona ilustracji wypukłej duże znaczenie w edukacji i rewalidacji niewidomego dziecka. Opracowała zasady adaptacji rysunku na potrzeby niewidomego odbiorcy (Więckowska, 2009b; Więckowska, red., 2011; Chojecka \& in., 2008). Materiały do nauki orientacji przestrzennej, redagowane pod kierunkiem s. Więckowskiej, szereg pozycji wydanych przez Studio Tyflografiki w Owińskach - to tyflografika poprawna merytorycznie i technicznie, a więc taka, której gromadzenie przez biblioteki publiczne, pedagogiczne, naukowe jest merytorycznie uzasadnione.

Aktualnie stosuje się technologię termoformowania próżniowego w materiałach transparentnych z pełnokolorowym poddrukiem. W poznańskim Studio Tyflografiki, pod kierunkiem Marka Jakubowskiego, opracowano nowatorskie technologie wykonywania matryc do tłoczeń tyflograficznych z termo- i duroplastów oraz żywic syntetycznych; opracowano sposób wykonywania matryc 3D, co pozwoliło na masowe wydawanie publikacji tyflokartograficznych i tyflograficznych.

W technologii tej wykonano (w nakładach 1000-2000 egz.) mapy tyflologiczne Poznania, Krakowa oraz plany reliefowe dla ogrodów botanicznych w Bolestraszycach, Powsinie i Bucharzewie. Wykonano ok. 100 przedstawień różnego rodzaju obiektów architektonicznych, w łącznym nakładzie kilku tysięcy egzemplarzy; opracowano obiekty z Poznania, Płocka, Warszawy oraz najbardziej zaawansowane technologicznie - z Krakowa, Tarnowa, Wrocławia i Nowego Sącza. Wyprodukowano m.in. reliefowe publikacje książkowe Moje ciało, Zwierzęta lasu polskiego, Polskie ptaki. Wydano również podręczniki do nauki orientacji przestrzennej oraz wypukłe gry edukacyjne (Jakubowski, 2009b; 2009c).

W wyniku prac zespołu eksperckiego, w skład którego wchodzili dyrektorzy specjalnych ośrodków szkolno-wychowawczych dla dzieci niewidomych i/lub słabowidzących, przedstawiciele uczelni wyższych wykonujących adaptacje podręczników na zlecenie MEN (Uniwersytet Warszawski, Katolicki Uniwersytet Lubelski Jana Pawła II, Uniwersytet Łódzki), Polskiego Związku Niewidomych i Ośrodka Rozwoju Edukacji, wypracowane zostały ujednolicone zasady adaptacji podręczników i ilustracji dla niewidomych:

1. Instrukcja tworzenia i adaptowania ilustracji i materiałów tyflograficznych dla uczniów niewidomych, opracowana przez zespół tyflopedagogów ze Specjalnych Ośrodków Szkolno-Wychowawczych w Polsce: Bydgoszcz, Kraków, Laski, Owińska 2011; 
2. Zasady tworzenia i adaptowania grafiki dla uczniów niewidomych, opracowane przez nauczycieli Specjalnych Ośrodków Szkolno-Wychowawczych dla Niewidomych i Słabowidzących w Polsce. Bydgoszcz, Laski, Łódź 2011 (Adaptacja podręczników..., 2016).

Dostępność materiałów instrukcyjnych z zakresu tworzenia tyflografiki oraz urządzeń technicznych do jej produkcji stwarza bibliotekom warunki do tworzenia reprezentacji wypukłych na indywidualne zamówienia użytkowników.

\section{SYSTEMATYZACJA TYFLOGRAFIKI}

Badania nad genezą i rozwojem tyflografiki pozwalają dokonać jej systematyzacji.

Szczegółowej klasyfikacji, według 14 kategorii podziału, dokonał M. Jakubowski. Do najistotniejszych (ze względu na praktykę biblioteczną) należą kategorie podziału tyflografiki:

a) ze względu na wykonawcę i odbiorcę na:

- wykonywane dla niewidomych i słabowidzących,

- wykonywane przez niewidomych i słabowidzących;

b) ze względu na sposób wykonania na:

- wykonywane ręcznie (jednostkowe egzemplarze),

- wykonywane mechanicznie (możliwość nieskończonej lub bardzo wielkiej ilości powtórzeń rysunku dotykowego);

c) ze względu na trwałość na:

- nietrwałe (jednorazowe),

- trwałe czasowo,

- bardzo trwałe;

d) ze względu na dostępność na :

- powszechnie dostępne,

- trudno dostępne lub niedostępne;

e) ze względu na miejsce wykonania na:

- krajowe,

- zagraniczne;

f) ze względu na rodzaj odbiorcy na:

- dla niewidomych,

- dla słabowidzących,

- uniwersalne;

g) ze względu na sposób wydania na:

- jednostkowe karty z przedstawieniem tyflograficznym,

- albumy,

- atlasy,

- książki ilustrowane,

- metalowe odlewy tyflografiki; 
h) ze względu na wysokość nakładu na:

- wysokonakładowe - tworzące rodzaj konkretnego standardu na terenie danego kraju w sensie ujednolicenia konkretnego rodzaju przedstawienia tyflograficznego,

- niskonakładowe - nietworzące standardów (Jakubowski, 2009b).

Badania M. Jakubowskiego pozwoliły również wyodrębnić 23 technologie wykonywania tyflografik, wśród których do najbardziej zaawansowanych należą: tłoczenie $\mathrm{w}$ plastiku (termouwypuklanie), drukowanie w technice fleksograficznej, drukowanie w sitodruku wypukłym, uwypuklanie na papierze pęczniejącym, drukowanie farbami gumowanymi, drukowanie klejowe z fakturowaniem spylonymi tkaninami (flock), wykonywanie tyflografik na mechanicznych ekranach dotykowych, wykonywanie tyflografik $\mathrm{w}$ technologii płukania polimerowego, wykonywanie tyflografik $\mathrm{w}$ technologii odlewu w polimerze lub masach plastycznych, tyflografika z syntezą mowy - audio touch (Jakubowski, 2009b).

Zaprezentowana powyżej systematyka może okazać się przydatna w procesie gromadzenia i opracowania (alfabetycznego i rzeczowego) tyflografiki jako alternatywnego materiału bibliotecznego.

\section{TYFLOPSYCHOLOGICZNE PODSTAWY TWORZENIA TYFLOGRAFIKI}

U podstaw tworzenia, gromadzenia, opracowania i udostępniania alternatywnych materiałów bibliotecznych znajdować powinna się wiedza tyflopsychologiczna, dotycząca specyfiki procesów poznawczych u osób z niepełnosprawnością wzroku. Na tej wiedzy oparte są zasady tworzenia prawidłowych rysunków dla niewidomych oraz ich odczytywania dotykowego.

Brak wzroku zakłóca zarówno poznanie bezpośrednie, jak i pośrednie. Podstawowym mechanizmem poznawania rzeczywistości przez niewidomych jest zjawisko kompensacji. W obrębie kompensacji poznawczej (kognitywnej) szczególnego znaczenia nabiera kompensacja zmysłów (sensoryczna), tłumaczona teorią tworzenia się dynamicznych układów strukturalnych w obrębie I i II układu sygnałowego (Grzegorzewska, 1964).

W przypadku braku zmysłu wzroku, jego rolę przejmują zmysły: dotyku, słuchu, węchu, smaku itp.

Szczególne znaczenie w percepcji i recepcji tyflografiki ma zmysł dotyku. Dotyk odbiera wrażenia: twardość, miękkość, gładkość, szorstkość. Pozwala poznać wielkość i kształt (niedokładnie). Jest zmysłem sekwencyjnym (wrażeń sukcesywnych), kontaktozmysłem (zmysł bliskonośny), zmysłem detekcyjnym, skórnym (obok zmysłu temperatury i bólu). W porównaniu ze wzrokiem, trudniej percypuje linię ciągła; jest zmysłem wrażeń przerywanych. Percepcja dotykowa powierzchni gładkiej jest trudniejsza niż punktów wypukłych. W jednym akcie postrzegania dotykowego percepo- 
wanych jest maksymalnie 6 elementów prostych. Łatwiej postrzegane są wrażenia uporządkowane niż bezładne. Dotyk dzieli się na syntetyczny (bierny) - służący tworzeniu ogólnych obrazów, schematów przedmiotów, analityczny (czynny) - pozwalający badać szczegóły przedmiotów, obejmujący - służący tworzeniu wyobrażeń trójwymiarowych i względny ułatwiający powstawanie wyobrażeń przestrzennych. Połączenie wrażeń dotykowych i kinestetycznych pozwala na odbiór właściwości przedmiotu: szorstkość, gładkość, elementarne cechy przestrzenne (długość, szerokość, wysokość, kierunek), wielkość i kształt (Pilecka, 1987; Majewski, 2002; Czerwińska, 2004).

Dzięki schematom dotykowym, możliwe jest tworzenie wyobrażeń przedmiotów. M. Grzegorzewska wyróżniła schematy dotykowe ogólne (tworzenie wyobrażenia przedmiotu na podstawie percepcji dotykowej charakterystycznych jego elementów) i formy (tworzenie wyobrażenia przedmiotu na podstawie dokładnej percepcji dotykowej jego wybranego, dostępnego fragmentu) (Grzegorzewska, 1964).

Wyobrażeniom dotykowym towarzyszą wyobrażenia kinestetyczne, odnoszące się głównie do stosunków czasowych, wspomagające tworzenie się wyobrażeń przestrzennych, będących sumą wyobrażeń przedmiotów, znajdujących się $\mathrm{w}$ przestrzeni. Wyobrażenia przestrzenne są rezultatem percepcji takich właściwości, jak: rozciągłość, kształt przestrzeni, kierunek, forma, położenie, głębokość, ruch. Wyobrażenia przestrzenne niewidomych są trójwymiarowe (Pilecka, 1987; Majewski, 2002; Czerwińska, 2004).

Czytanie rysunku jest działaniem w przestrzeni: niewidomy przesuwa palce po powierzchni arkusza. Istotną trudnością jest tutaj ograniczenie pola obserwacji dotykowej i niemożność zastosowania struktury liniowej, jak przy czytaniu tekstu. Niewidomy dotyka niewielkiego fragmentu rysunku; przesuwając palce, zapoznaje się z kolejnymi jego fragmentami. Objęcie wyobraźnią całości rysunku wymaga dużego wysiłku i wyćwiczenia, gdyż rysunek wypukły nie jest dla niewidomego podobny do przedmiotu, lecz „opowiada” o tym przedmiocie; wrażenia odbierane końcami palców podczas odczytywania wypukłego obrazka przedmiotu są zupełnie inne, niż wrażenia odbierane przy oglądaniu prawdziwego przedmiotu za pomocą dotyku obejmującego. Niewidomy nie uczy się spontanicznie konwencji rysunkowych; podlegają one świadomemu wyuczeniu (Chojecka \& in. 2008).

W świetle powyższego, prawidłowo wykonana tyflografika musi być opracowana (poddana adaptacji). Jest to proces przeredagowania prezentacji płaskiej do postaci wypukłej, polegający na:

1. Zmianie konwencji - sposobu przedstawienia. Niewidomym dostępne są następujące konwencje rysunków: rysunek geometryczny figur płaskich oraz rysunek konstrukcyjny na płaszczyźnie; rysunek ilustracyjny w konwencji rzutu prostokątnego (widok), bez zbędnych szczegółów; 
rzut przedmiotu na jedna, dwie i trzy płaszczyzny; scena - rysunek kilku przedmiotów, nie zasłaniających jeden drugiego; rysunek przedmiotu w przekroju; plan izby, budynku, terenu, miasta; mapa w dowolnej skali i odpowiednim poziomie generalizacji; wykres zależności funkcyjnej; diagram; rysunek wektorowy, schemat elektryczny, schemat komunikacyjny.

Niedostępnymi konwencjami są: rzut ukośny (widok z lotu ptaka) i perspektywa zbieżna (Chojecka \& in. 2008).

2. Zmianie skali - powiększenie obrazu czytelnego dla widzących.

3. Zmianie poziomu generalizacji - uszczegółowienia, (rezygnacja $\mathrm{z}$ mniej istotnych treści).

4. Podziale treści ilustracji na kilka prezentacji tego samego obiektu, wykonanych w tej samej lub w innej niż oryginał konwencji.

5. Zmianie linii, znaków i kolorów oryginalnego rysunku - na zróżnicowane linie, faktury powierzchniowe, inne oznaczenia wypracowane i sprawdzone wcześniej (opracowanie tyflograficzne).

6. Uproszczeniu rysunku do prezentacji czytelnej dotykiem i uzupełnieniu jej opisem (Chojecka \& in. 2008).

Tyflografika powinna być czytelna, czyli wypukłości kształtów, punktów, znaków, linii oraz faktur określających wyróżnione powierzchnie - muszą być łatwo rozpoznawane dotykowo. nie stosuje się punktów, linii wklęsłych.

Zaleca się, aby tyflografika była użyteczna - nie należy produkować ilustracji nie przekazujących użytkownikowi żadnych informacji. Ozdobniki, cienie i inne urozmaicenia, atrakcyjne estetycznie w odbiorze wzrokowym, dla osoby niewidomej i słabowidzącej są przeszkodą w czytaniu.

Tyflografika musi mieć umowny znak, określający prawidłowe zorientowanie arkusza.

Tyflografika powinna „opowiadać" o przedmiocie, a nie być podobna do przedmiotu, a zatem - musi mieć wartość poznawczą.

Wielkość tyflografiki powinna wynikać z zależności: im mniejsza tyflografika - tym łatwiej ją przeczytać, objąć wyobraźnią; im bogatsza treść tyflografiki - tym większe muszą być jej wymiary.

Użyteczne jest łączenie tyflografik $\mathrm{w}$ albumy lub atlasy o określonej tematyce, gdyż ułatwia zachowanie porządku w zbiorach. Tomy nie mogą jednak być grube i ciężkie, gdyż utrudnia to operowanie nimi. Najkorzystniejsze wydaje się gromadzenie zbiorów tyflografik $\mathrm{w}$ formie cienkich zeszytów, których okładki zapobiegną szybkiemu niszczeniu materiałów, a rozmiar nie utrudni posługiwania się nimi (Chojecka \& in., 2008; Więckowska, 2009b; Więckowska, red., 2011).

Podstawowa wiedza tyflopsychologiczna na temat specyfiki procesów poznawczych u osób z głęboką niepełnosprawnością wzroku i wynikające z niej zasady tworzenia tyflografiki - wskazują na znaczenie rysunku wypukłego jako nośnika informacji, którego udostępnianie w bibliotekach jest bezspornie wskazane. 


\section{ZAKOŃCZENIE}

Tyflografice przypisuje się cele poznawcze, kształcące, wychowawcze, rozrywkowe i rehabilitacyjne. Prawidłowo zredagowana i wyprodukowana tyflografika informuje bowiem o pojęciach przestrzennych (pojęcia geometryczne i z zakresu orientacji), o kształtach przedmiotów (widok, rzut, rzuty, przekrój), o relacjach przestrzennych między przedmiotami (plan, mapa). Pełni istotną rolę w przekazywaniu informacji o obiektach i zjawiskach, niemożliwych do bezpośredniego poznania dotykowego (zbyt małe, zbyt delikatne, za duże, niebezpieczne, lub poruszające się) (Więckowska, red., 2011).

Podstawowym warunkiem użyteczności grafik dotykowych jest edukacja graficzna niewidomych, zmierzająca do nauczenia ,języka" grafiki (Więckowska, 2009b).

Niestety, nauczanie rysunku w polskich szkołach dla niewidomych nie jest powszechne. W wielu krajach rysunek wypukły dla dzieci niewidomych wprowadza się już od piątego roku życia. Opracowuje się książeczki rozrywkowo-edukacyjne. Tymczasem polscy niewidomi funkcjonują $\mathrm{w}$ „paradoksie informacyjno-komunikacyjnym”. Posługują się nowoczesnymi technologiami informacyjno-komunikacyjnymi, a jednocześnie nie potrafią odczytywać najprostszej grafiki dotykowej, co prowadzi do wykluczenia informacyjnego.

Przygotowanie niewidomych do samodzielnego życia w społeczeństwie wymaga wczesnego ćwiczenia umiejętności odczytywania i rozumienia rysunku (Chojecka \& in., 2008).

W obliczu nakreślonej sytuacji, wprowadzenia i upowszechnienia wymagają zasady redagowania ilustracji dostosowanej do odczytu dotykiem i słabym wzrokiem.

Zadaniem dla bibliotekarzy, we współpracy z tyflopedagogami, powinno być stworzenie centralnej bazy poprawnie zredagowanych tyflografikdostępnej dla edukatorów, rehabilitantów, rodziców dzieci niewidomych i samych osób z niepełnosprawnością wzroku.

Niewątpliwie należy popierać tworzenie edukacyjnej i rozrywkowej książki dla osób niewidomych i słabowidzących (zwłaszcza dzieci), bogato ilustrowanej za pomocą prawidłowo zredagowanej i wytworzonej tyflografiki. Lektura takich publikacji książkowych umożliwi efektywną edukację i rehabilitację oraz inkluzyjne uczestnictwo osób z niepełnosprawnością wzroku we współczesnym życiu społecznym i kulturalnym.

Do rozwoju tyflografiki w Polsce wydatnie przyczynić się może środowisko bibliotekarskie. Objęcie tyflografiki procesem gromadzenia zbiorów (włączenie jej do materiałów alternatywnych) - uczyni ją bardziej dostępną niepełnosprawnym wzrokowo użytkownikom, ich opiekunom, edukatorom, rehabilitantom. Wykorzystanie tyflografiki (plany, makiety wypu- 
kłe) w informowaniu o przestrzeni bibliotecznej i okołobibliotecznej ułatwi niewidzącym użytkownikom orientację przestrzenną i samodzielne poruszanie się w bibliotece i w jej pobliżu. Bibliotekarze obsługujący użytkowników z niepełnosprawnością wzroku mogą stać się znawcami ich potrzeb w zakresie materiałów tyflograficznych; wiedza ta jest niezwykle cenna dla profesjonalnych producentów tego typu publikacji. Przy odpowiednim wyposażeniu technicznym i wiedzy tyflopsychologicznej bibliotekarze mogą sami wytwarzać proste rysunki wypukłe, książeczki dotykowe dla niewidomych dzieci, zaspokajając doraźne potrzeby swoich użytkowników. Kompetencje bibliotekarskie są niezbędne w profesjonalnym katalogowaniu rozproszonej produkcji wydawnictw tyflograficznych - polskich i zagranicznych, historycznych i współczesnych.

Tyflografika jest szansą dla książki niewidomego oraz jej użytkowników - pozostaje sposobem na pełnoprawną obecność niewidomych w świecie informacji. W realizacji tej szansy niebagatelną rolę mają bibliotekarze.

\section{BIBLIOGRAFIA}

Adaptacja podręczników [online], [dostęp: 20.05.2016]. Dostępny w WWW: <http://www.ore.edu. pl $>$ (Wydziały ORE $\rightarrow$ Specjalnych Potrzeb Edukacyjnych $\rightarrow$ Adaptacja podręczników).

Atlas Geograficzny Europy. Warszawa: Główny Urząd Geodezji i Kartografii, Polski Związek Niewidomych 2006.

Atlas Geograficzny Polski. Warszawa: Główny Urząd Geodezji i Kartografii, Polski Związek Niewidomych 2004.

Bendych, Ewa (1994). Badania nad rysunkiem niewidomego dziecka. Cz. 1. Szkoła Specjal$n a$, nr 5, s. 276-287.

Bendych, Ewa (1995a). Badania nad rysunkiem niewidomego dziecka. Cz. 2. Szkoła Specjalna, nr 1, s. 3-15.

Bendych, Ewa (1995b). Badania nad rysunkiem niewidomego dziecka. Cz. 3. Szkoła Specjal$n a$, nr 3, s. 141-153.

Cackowska, Maria (2009). Czym jest książka obrazkowa? O pojmowaniu książki obrazkowej w Polsce. Cz. 1. Ryms - Kwartalnik o Ksiażkach dla Dzieci i Młodzieży, nr 5, s. 9 [online], [dostęp: 20.05.2016]. Dostępny w WWW: <http://ryms.pl/artyuLszczegoly/12/ index.html>.

Cackowska, Maria (2009). Czym jest książka obrazkowa? O pojmowaniu książki obrazkowej w Polsce. Cz. 2. Ryms - Kwartalnik o Ksiażkach dla Dzieci i Młodzieży, nr 6, s. 14-16 [online], [dostęp: 20.05.2016]. Dostępny w WWW: <http://ryms.pl/artyuLszczegoly/12/ index.html>.

Cackowska, Maria (2009/2010). Czym jest książka obrazkowa? O pojmowaniu książki obrazkowej w Polsce. Cz. 3. Ryms - Kwartalnik o Ksiażkach dla Dzieci i Młodzieży, nr 8, s. 12-13 [online], [dostęp: 20.05.2016]. Dostępny w WWW: <http://ryms.pl/artyuLszczegoly/12/index.html>.

Chojecka, Anna; Magner, Marian; Szwedowska, Elżbieta; Więckowska, Elżbieta (2008). Nauczanie niewidomych dzieci rysunku: Przewodnik dla nauczyciela. Laski: TOnO.

Cybulski, Radosław (1986). Ksiażka wspótczesna: Wydawcy, rynek, odbiorcy. Warszawa: PWN. 
Czerwińska, Małgorzata (1999). Pismo i ksiażka w systemie Louisa Braille'a w Polsce. Historia i funkcje rewalidacyjne. Warszawa: Wydaw. SBP.

Czerwińska, Małgorzata (2004). Niewidomy. W: Encyklopedia pedagogiczna XXI wieku. T. 3: M-O. Warszawa: Wydaw. Akademickie „Żak”, s. 685-693.

Czerwińska, Małgorzata (2015). Early support in the development of blind children by means of a Braille system and tactile books. W: Early support for a Child with a Disability in the Polish and International Perspective. Eds. J. Bąbka, A.I. Brzezińska. Toruń: Wydaw. Adam Marszałek, s. 112-130.

Fedorowicz, Małgorzata (2002). Specjalne materiały czytelnicze dla osób niepełnosprawnych: Zarys dziejów, formy, obieg społeczny. Toruń: Wydaw. UMK.

Fedorowicz-Kruszewska, Małgorzata; Cyrklaff, Magdalena J. (2016). Media w środowisku osób zagrożonych wykluczeniem społecznym. Toruń: Wydaw. WSB.

Fromm, Wolfgang (1983). Zasady i metody percepcji rysunków wypukłych. Review of European Blind, nr 4 (XLII) (mps tłum. pol., Bibl. Tyfl., Laski).

Głombiowski, Karol (1980). Ksiażka w procesie komunikacji społecznej. Wrocław-Warszawa-Kraków-Gdańsk: Zakład Narodowy im. Ossolińskich, Wydaw. Polskiej Akademii Nauk.

Głombiowski, Karol (1985). Teoria i metodologia nauki o książe. Gdańsk: Wydaw. Uniwersytetu Gdańskiego.

Grzegorzewska, Maria (1964). Wybór pism. Warszawa: PWN.

J. W. (Janina Wiercińska) (1982). Ilustracja. W: Współczesne polskie drukarstwo i grafika ksiażki: Mały stownik encyklopedyczny. Red. B. Kleszczyński, K. Racinowski. Wrocław: „Ossolineum", s. 109-112.

Jakubowski, Marek (2009a). Trwałe tyflografiki na nietrwałym papierze. Tyfloświat, nr 4 (6), s. 48-54 [online], [dostęp: 20.05.2016]. Dostępny w WWW: <http://www.firr.org.pl/ uploads/PUB/Tyfloswiat_4_2009_0.pdf>.

Jakubowski, Marek (2009b). Tyflografika - historia i współczesność, metody i technologie. Tyfloświat, nr 1(3), s. 36-40 [online], [dostęp: 20.05.2016]. Dostępny w WWW: <http:// www.firr.org.pl/uploads/PUB/Tyfloswiat-01_2009.pdf>.

Jakubowski, Marek (2009c). Tyflografika - ksero dla niewidomych. Tyfloświat, nr 2 (4), s. 8-11 [online], [dostęp: 20.05.2016]. Dostępny w WWW: <http://www.tyfloswiat.pl/ files/Tyfloswiat_2_2009_1.pdf>.

Jakubowski, Marek (2010). Zrób to sam - narzędzie do tworzenia tyflografik. Tyfloświat, nr 1 (7), s. 32-43 [online], [dostęp: 20.05.2016]. Dostępny w WWW: <http://www.firr. org.pl/uploads/PUB/tyfloswiat_1_2010_0.pdf>.

Kaczmarek, Anna, red. (2003). Nowoczesne techniki ksztatcenia dzieci niewidomych i stabowidzacych. Europejska Konferencja, Owińska, 25-26.04.2003 r. Poznań: Wydaw. eMPi2.

Kazanowska, Bożena (2012). Książki dotykowe dla małych dzieci - czyli zrób to sam. W: Jakprzygotować niewidome dziecko do nauki Brajla? Przewodnik dla rodziców i nauczycieli. Red. M. Paplińska. Warszawa: Fundacja Polskich Niewidomych i Słabowidzących „Trakt”, s. 96-104.

Komza, Małgorzata (1987). Mickiewicz ilustrowany. Wrocław: „Ossolineum”.

Lachów, Wola N (1978). Szkice z teorii sztuki ksiażki. Wrocław-Warszawa-Kraków-Gdańsk: Zakład Narodowy im. Ossolińskich, Wydaw. Polskiej Akademii Nauk.

Lewandowicz-Nosal, Grażyna (2012). Od czterech do sześciu: Książki dla przedszkolaka. Warszawa: Wydaw. SBP.

Majewski, Tadeusz (2002). Tyflopsychologia rozwojowa: Psychologia dzieci niewidomych i stabowidzacych. Warszawa: PZN. 
Malinowska, Tekla; Syta, Ludwik (1981). Redagowanie techniczne ksiażki. Warszawa: WNT.

Mendruń, Józef; Oleksiak, Elżbieta, red. (2010). Tyflokartografia. Przegląd Tyflologiczny, nr 1-2 (40-41).

Migoń, Krzysztof (2003). Bibliologiczne problemy książki ilustrowanej. W: Sztuka książki: Historia - teoria - praktyka. Red. M. Komza. Wrocław: Wydaw. Uniwersytetu Wrocławskiego, s. 13-34.

Pilecka, Władysława (1987). Wybrane zagadnienia tyflopsychologii. W: Psychologia defektologiczna. Red. A. Wyszyńska. Warszawa: PWN, s. 85-113.

Skierkowska, Elżbieta (1969). Współczesna ilustracja ksiażki. Wrocław: Zakład Narodowy im. Ossolińskich - Wydawnictwo.

Słońska, Irena (1977). Psychologiczne problemy ilustracji dla dzieci. Warszawa: PWN.

Szuman, Wanda (1967). O dostępności rysunku dla dzieci niewidomych. Warszawa: Państwowe Zakłady Wydawnictw Szkolnych.

Talukder, Alina (2009). Życie dziecka bez obrazków. Tyfloświat, nr 1(3), s. 36-40 [online], [dostęp: 20.05.2016]. Dostępny w WWW: <http://www.firr.org.pl/uploads/PUB/Tyfloswiat-01_2009.pdf>.

Talukder, Alina; Jakubowski, Marek (2003). Technologia tworzenia map i planów wypukłych dla niewidomych i słabowidzących. Owińska: Ośrodek Szkolno-Wychowawczy dla Dzieci Niewidomych.

Vrtel-Wierczyński S. (1951). Teoria bibliografii w zarysie. Wrocław: Zakład Narodowy im. Ossolińskich.

Wiercińska, Janina (1986). Sztuka i książka. Warszawa: PWN.

Więckowska, Elżbieta (2009a). Tyflografika. Szkoła Specjalna, nr 1, s. 53-65.

Więckowska, Elżbieta (2009b). Zasady redagowania tyflografiki. Tyfloświat, nr 3(5), s. 7-13 [online], [dostęp: 20.05.2016]. Dostępny w WWW: <http://www.firr.org.pl/uploads/ PUB/Tyfloswiat-03_2009.pdf>.

Więckowska, Elżbieta (2011). Tyflografika - konieczność czasu. W: Środowisko Lasek w perspektywie historii i chrześcijańskiej myśli pedagogicznej. Red. J. Placha. Warszawa: Wydaw. UKSW, s. 283-291.

Więckowska, Elżbieta, red. (2011). Instrukcja tworzenia $i$ adaptowania ilustracji i materiałów tyflograficznych dla uczniów niewidomych. Opracowana na zlecenie Departamentu Zwiększania Szans Edukacyjnych Ministerstwa Edukacji Narodowej, przez zespół tyflopedagogów ze Specjalnych Ośrodków Szkolno-Wychowawczych w Polsce w składzie: Marek Jakubowski (Owińska) , Krystyna Kauba (Laski), Leszek Ogórek, Jolanta Ogórek (Kraków), Iwona Pawłowska (Warszawa), Alina Talukder (Owińska), s. Elżbieta Więckowska (Laski). Bydgoszcz, Laski, Kraków, Owińska (mps, Bibl. Tyfl., Laski).

Artykut wptynąt do Redakcji 28 marca 2017 r. 
Małgorzata Czerwińska

The University of Zielona Góra

e-mail: gosiajoanna@wp.pl

\section{TACTILE GRAPHICS - AN OPPORTUNITY FOR A NEW SHAPE OF BOOKS FOR THE VISUALLY IMPAIRED AND THE PRESENCE OF THEIR USERS IN THE INFORMATION WORLD? REFLECTIONS ON THE BOOK STUDIES AND TACTILE GRAPHICS}

KEYWORDS: Tactile graphics. Illustration. Raised representation. The blind. Cognitive processes. Education. Rehabilitation.

ABSTRACT: Thesis/Objective - The article is intended to present and systematize basic knowledge in the area of tactile graphics, that is, palpable representation of signs for the visually impaired, psychological conditions of its design, production and application in the processes of education and rehabilitation and its inclusive role in the social involvement of the visually impaired, including their access to information and cultural resources. The author wants to introduce the issue of tactile graphics and raised graphic representation as the elements of books for the blind into the area of book studies. Research methods - Published and unpublished sources and the participant observation was used to present a comparison of concepts and terms from the area of traditional book illustration and tactile graphics. Results and conclusions - The origins and evolution of tactile graphics around the world and in Poland were described with focus on the significance of Martin Kunz's activity in this area. The contemporary systematization of tactile graphics was presented. Referring to the basic psychological knowledge on the cognitive processes of the blind, the author discussed key rules for developing correct tactile representations. The article ends with a list of postulates the implementation of which guarantees that tactile graphics performs its cognitive, entertaining, informative, educating and rehabilitating functions. 